\title{
THEORETICAL ASPECTS OF INTEGRATIVE PROCESSES IN TEACHING A FOREIGN LANGUAGE FOR PROFESSIONAL PURPOSES
}

\author{
ТЕОРЕТИЧНІ АСПЕКТИ ІНТЕГРАЦІЙНИХ ПРОЦЕСІВ \\ У ВИКЛАДАННІ ІНОЗЕМНОЇ МОВИ ПРОФЕСІЙНОГО СПРЯМУВАННЯ
}

\author{
Holubova H.V. \\ orcid.org/0000-0003-1420-0591 \\ Candidate of Pedagogical Sciences, \\ Assistant Professor at the Department of Foreign Languages \\ Odessa National A. V. Nezhdanova Academy of Music
}

The article is devoted to the analysis of integration processes in teaching a foreign language for professional purposes. It is determined that integration processes in professional education are of significant importance since they are aimed at developing a holistic system of students' knowledge and skills at non-linguistic institutions of higher education and improving of their creative abilities and potentials. The integrative tendencies in professional education are determined by the enhancing role of interdisciplinary knowledge and common scientific methods of intensifying students's cognitive activity.

During theoretical and methodological analysis of the scientific investigations the essence of the concepts «integration», «integration in education» were specified. Theoretical aspects of the application of integration processes in the formation of foreign language communicative competence were considered, including the use of integrative approach in foreign language teaching. The integrity of theoretical and practical elements of training, obtained in different disciplines and activities, allows the future specialists to increase their professional level. The elements of integration processes are presented in ideas, concepts, worldviews and generalizations, skills and abilities, along with the purpose, methods, means, learning environment, etc. As integration is one of the key factors in the future professionals' training, the learning based on an integrative approach is especially relevant in the modern education system. Given its ability to provide qualitatively new conditions for the higher education applicants' communicative competence formation, the integrative approach determines the teaching methods and strategies based on the integration of certain fields of knowledge, subjects, disciplines, etc. Considering the utter openness of a foreign language to numerous interdisciplinary connections and applying information from other subject areas, the implementation of an integrative approach in teaching a foreign language for professional purposes is especially relevant. It stimulates the future specialists' self-determination and self-realization in various fields of professional and related activities, holistic development of the personality, establishment of closer connections of training with practical activity, and thus promotes the formation of comprehensively developed personality and foreign language communicative competence of the future professionals of non-linguistic specialties.

Key words: integration, integration in education, foreign language communicative competence, integrative approach, integrative technologies.

Статтю присвячено аналізу проблеми інтеграційних процесів у викладанні іноземної мови професійного спрямування. Установлено, що інтеграційні процеси у професійній освіті мають суттєве значення, оскільки вони спрямовані на розвиток цілісної системи знань та вмінь студентів нелінгвістичних закладів вищої освіти, вдосконалення їхніх творчих здібностей та потенціалу. Під час теоретико-методологічного аналізу наукових досліджень було уточнено сутність понять «інтеграція», «інтеграція в освіті». Інтеграційні тенденції у професійній освіті визначаються посиленням ролі міждисциплінарних знань та загальнонаукових методів активізації пізнавальної діяльності здобувачів вищої освіти. Розглянуто теоретичні аспекти застосування інтеграційних процесів у формуванні іншомовної комунікативної компетентності, зокрема використання інтегративного підходу у викладанні іноземних мов. Цілісність теоретичних та практичних елементів навчання, отриманих із різних дисциплін та видів діяльності, дає змогу майбутнім спеціалістам підвищувати свій професійний рівень. Елементи інтеграційних процесів представленл в ідеях, концепціях, світоглядах та узагальненнях, уміннях і навичках разом із метою, методами, засобами, середовищем навчання тощо. Оскільки інтеграція $є$ одним із ключових чинників підготовки майбутніх фрахівців, навчання на основі інтегративного підходу особливо актуальне у сучасній системі освіти. Ураховуючи здатність забезпечити якісно нові умови для формування комунікативної компетентності здобувачів вищої освіти, інтегративний підхід визначає методи та стратегії навчання на основі інтеграції певних галузей знань, предметів, дисциплін тощо. Спираючись на відкритість іноземної мови до численних міждисциплінарних зв'язків та застосування інформації з інших предметних сфер, реалізація інтегративного підходу у навчанні іноземної мови професійного спрямування особливо актуальна, зважаючи на її вагомий внесок у цілісний розвиток особистості, стимулювання самовизначення та самореалізації майбутніх фахівців у різних сфрерах професійної та суміжної діяльності, встановлення зв'язків навчання з практичною діяльністю, а отже, формування іношомовної комунікативної компетентності майбутніх фахівців нелінгвістичних спеціальностей.

Ключові слова: інтеграція, інтеграція в освіті, іншомовна комунікативна компетентність, інтегративний підхід, інтегративні технології.

Setting of the problem and relevancy substantiation. In the period of modern globalization the problem of integrating the content of education becomes one of the most important aspects of its reformation. Modern economic, cultural and sociopolitical processes have led to the need of rethinking 
the purpose of learning a foreign language in the higher school. In the modern socio-economic conditions the increasing role of a foreign language as a means of intercultural communication results in the growing importance of integration in education.

As an independent scientific phenomenon, integration revealed itself in pedagogy in the first half of the 1980s as a result of interconnected processes in economic, social, political, information and other spheres of life along with the need of perceiving the educational and social processes in complex. Eventually, the term «integration» became widespread in almost all the scientific areas of research, being interpreted as a wide range of unifying processes and tendencies, thus having different semantic meanings.

Integration in the educational process is understood as interpenetration of elements of one object into the structure of another, resulting in the formation of a completely new object with its own characteristics of the organization (M. Berulava, R. Hurevich, M. Mahmutov). In the educational process integration is provided through combining in a single synthesized course (topic, section of the program) the elements of different disciplines, scientific concepts, methods, merging the basics of sciences in the substantiation of interdisciplinary problems. Thus, the content of education is the basis for implementing the principles of integration in the educational process, which is provided by the integration of the content of academic disciplines.

The substantiation of the content of academic disciplines, implementing integration is a continuous and difficult process, which consists in the developing of certain innovative teaching forms and methods, thejointefforts of scientists, teachers and professionals. Integration processes in professional education have recently been of a significant importance, as they are aimed at forming a holistic system of individual's knowledge and skills, the development of their creative abilities and potential. Therefore, the investigation of an integrative approach to the foreign language teaching is still relevant.

Analysis of recent research and publications. The issues of integration in education are reflected in the works of domestic and foreign scholars, such as: H. Baturina, S. Batysheva, N. Borisko, V. Borisov, V. Filipov, E. Hlinskaya, Y. Kozlovsky, V. Kushnir, N. Kuznetsova, R. Martynova, V. Maslov, Yu. Passov, P. Pattison, N. Potello, P. Serdyukov, N. Serdyukova, S. Smirnov, V. Sulim, Y. Tyunnikov, N. Yevtushenko, I. Zverev, etc. Integration processes in professional education were considered by such well-known scientists as V. Davydov, I. Lerner, V. Onischuk, V. Palamarchuk, M. Skatkin, V. Sukhomlinsky and others. However, despite the large number of publications on this issue, the phenomenon «integration» remains the subject of heated discussions, while insufficient attention is paid to justifying the feasibility of using the integrative approach as a means of forming the future specialists' foreign language competence.

The purpose of the article is to specify the concept «integration» and consider theoretical aspects of applying the integration processes in the formation of a foreign language communicative competence, in particular, the use of an integrative approach in teaching a foreign language of professional orientation.

Presentation of the main research material. The problem of knowledge integrity under current conditions is a necessary component of the education content formation. Applicants for higher education should be focused on the improvement of their own professional competence, the development of communicative skills, the use of the language as a means of communication to implement the professional tasks. Based on the analysis of psychological and pedagogical literature, it becomes clear that integration is one of the key factors in the future professionals' training.

In the field of education, integration is interpreted as a key principle for the development of modern educational systems. Integration in education is an association, organic convergence of educational institutions, systems, the content of educational programs, various subjects or subject areas [3, p. 198]. Integration serves as a process of merging, the result of which is achieving the unity and integrity, consistency within a system, which is based on the interdependence of individual specialized elements [17, p. 291].

There are dozens of types of integration in scientific circulation: pedagogical, didactic, managerial, psychological, state, social, integration of educational influences, etc. [7, p. 4]. According to K. Shevchuk, integration in education impliments the following functions: educational, educative, developmental, psychological, methodological, organizational; it has various forms: subject-imaginative, conceptual, ideological, functional, conceptional [18].

At the sametime, integrationis the vertex of creative self-developmentofeducation, anattemptoftraditional pedagogy to overcome itself, to decisively reconsider its own basis: didactic fragmentation of academic disciplines and mechanical sequence of classes detached from life [4, p. 22]. Integration serves as a means of universal human education because it is considered as the principle of the educational process, which is based on the complementarity of various 
forms of knowledge about reality, which creates conditions for an establishment of multidimensional picture of the world and self-identification in it [7].

Applying the integration bases of learning promotes system-integrative perception of knowledge in various subjects, simultaneous activation of knowledge perception and its systematization, knowledge improving and advancing, educating of a comprehensively developed personality. All the above mentioned interpretations are related to such a type of integration as subjective integration, which is characterized by the following features: semantic content (synthesis of knowledge from different branches of science, which are united by a common content); subject integrity (combination of different elements that lose their primary characteristics and acquire new ones, inherent only in subject integrity) [11]. Another logical term of integrated learning is «integration on a procedural basis», when in a single process a synthesis of educational objectives is performed, as well as of the educational discipline components and learning content components, methods and teaching means, control over the learning outcomes of professional and foreign language speech activity are implemented [12].

The idea of integration in education is a significant attainment in didactics, since on condition of its successful methodological implementation the objective of qualitative education is realized. Therefore, integration as a requirement to unite the components of learning objects is a necessary didactic means, which allows the students to create a holistic view of the object being studied, thus forming interdisciplinary competence.

Obviously, the non-mechanical integration of the subjects or their components, as well as the borderlines of the knowledge system within one discipline is presented by integration. The necessary condition for integration is the availability of a fundamental idea, the implementation of which can ensure the integrity of the training course (not a mechanical integration of knowledge, but the synthesis and creation of a system of integrated, holistic, interconnected knowledge).

In the scientific literature, the variety of integration forms is considered from different approaches (systemic, systemic-targeting, functional), which, in its turn, confirms the availability of integration processes in various aspects of education system. The predominant directions of integration are considered the following: integration by the objectives of educational process, integration by the content, as well as by the forms and methods. Scientists identify three forms of integration: complete, partial and compound integration, where the first is characterized by the synthesis of educational material of different disciplines in one course, partial - by a combination of the material from different disciplines, subordinate to one topic; compound - by constructing the autonomous blocks with independent programs.

According to the processes direction parameter, the scientists (I. Krapivna, M. Mahmutov, $\mathrm{H}$. Fedorets) distinguish the external and internal integration. Under the external one they understand the unity, the connection of the certain parts of the subjects content; internal integration involves the interpenetration of components, which occurs within a single discipline.

There are different levels of integration: integration within a theme; integration within a section of educational material; integration within one discipline; integration within related disciplines; integration between disciplines of different cycles and even integration as a special didactic principle of teaching. There also can be mentioned integration technologies in pedagogy meaning didactic systems that provide integration of knowledge and skills from different subjects, educational topics, educational problems and other forms of learning, different activities within integrated courses [5, p. 74].

Considering the issue of integration within the framework of education requires reliance on general pedagogical, didactic, educational, administrative laws and patterns. Integration of knowledge, meaning the definition of related elements of the content and combining them into a certain integrity, is a rather complex process that is subject to certain laws, such as:

1. The law of correlation: the elements of integration must be distinguished by the properties that ensure their ability to coordinate the interaction.

2. The law of imperativity: the process becomes integrative only when the following conditions are met, namely: the emergence of qualitatively new properties as a result of integration; the availability of the system-structural nature of the new integrative object; maintaining of individual features of integration elements; the existence of several stable states of the integrated object.

3. The law of complementarity: integrative processes lead to the implementation of those differentiative [109, p. 16-17].

In the context of integration, the idea of using interdisciplinary links in the educational process is becoming increasingly popular. This is especially true of learning a foreign language in the higher school, as knowledge of a foreign language enables 
studying certain disciplines using information from foreign English-language sources. The possession of a foreign language allows to expand student's horizons, therefore advancing the knowledge in a particular area [6, p. 138]. Thus, integration is considered as a process of rapprochement and connection of sciences, operating along with the process of differentiation, which is the highest form of interdisciplinary links objectification at a qualitatively new level of education [8].

The essence of integrative tendencies in professional education is determined by the enhancing role of interdisciplinary knowledge and common scientific methods of intensifying students's cognitive activity. The integrity of theoretical and practical elements of training, obtained in different disciplines and activities, allows the future specialists to increase their professional level. Thus, the process of integration is manifested in the structuring, presenting and mastering of the disciplines content, which provides systematic teaching of subjects in terms of the new coordinated connections. Elements of integration processes are presented in ideas, concepts, worldviews and generalizations, skills and abilities, along with the purpose, methods, means, learning environment, etc.

Since the specialists' holistic professional training is divided into the subjects, there is a real menace of fragmentation in the knowledge and skills acquiring. Therefore, there is a need to improve the entire system of educational work in the higher school, in particular to expand the future professionals' cognitive activity, to form their skills of mastering the methods of cognition. There is a need to apply the integrative approach to the future professionals' training, which will undoubtedly enable the balancing of methodological differentiation of professional training.

Learning based on an integrative approach is especially relevant in the modern education system, given its ability to provide qualitatively new conditions for the higher education applicants' communicative competence formation. Under the conditions of awaring the principles of interdisciplinary integration, which should be the basis of education in professional school, the effectiveness of highly qualified future professionals' training is increased and intensified. We consider that qualitative professional training of the students will be carried out more effectively provided the use of an integrative approach, which determines the teaching methods and strategies based on the integration of certain fields of knowledge, subjects, disciplines, etc.

The integrative approach to learning stimulates the consolidation of the education content, i.e. the viable integration of its elements into an entity. The result of the integrative approach is the integrity of different knowledge levels - the integrity of knowledge about reality, nature; knowledge in one or another educational field, subject, course, section, topic. The integrative approach is implemented while studying the integrated courses or certain subjects in the education area, when the entity of knowledge is formed through its integration on the basis of common concepts for all the subjects; application of methods and forms of teaching, control and correction of students' academic achievements, which direct the educational process to the integration of knowledge [3, p. 198]. According to O. Semenog, the coordinated use of cross-cutting ideas on an integrative basis is one of the main approaches to improving the content of education [17, p. 292]. The integrative approach to the teaching of disciplines now turns from the coordination of the content of education to deep interaction, reasonable integration of the future specialist' knowledge and skills.

The integrative approach to organizing the educational process involves taking into account the theoretical foundations of integration and the specifics of a particular institution in order to improve the level and quality of professional knowledge [2, p. 18]. According to I. Kozlovska, the integrative approach to learning is carried out by didactic substantiation and transformation of real connections between the concepts, phenomena, sciences, etc. The integrative approach is defined as the pursuit to combine, harmonize, coordinate, coherently use the efforts and capabilities of numerous parties, participants, subjects. The integrative feature should be understood not only externally as versatility, unification, but also internally as coherency, self-similarity, orientation and acmeologicity of the components of higher education [8, p. 3].

The main ways to provide integration in the educational process, which reveal the essence of an integrative approach, are the following:

- structuring of the educational material;

- realization of interdisciplinary and intrasubject connections: the use of complex tasks, the tasks with interdisciplinary content;

- application of logical operations that lead to the interaction of disparate elements of the learning process (different types of generalization, analysis of technical objects, specification, modelling, etc.);

- systematization of scientific concepts, distinguishing the fundamental, generalizing concepts in a single system of knowledge;

- realization of the idea of knowledge continuity, brightening of perspective and retrospective 
lines of science development and demonstration of possibilities of systematized, integrated knowledge;

- using the problem presentation of educational material, selecting adequate principles and methods of teaching [8].

It is well known that among all the disciplines, foreign language, like no other one, is open to numerous interdisciplinary connections, to the use of information from other subject areas. In the aspect of our research, the implementation of an integrative approach of teaching a foreign language in the educational process helps to provide specialist' self-determination and self-realization in various fields of professional and related activities, development of systematic thinking, creation of conditions for holistic development of personality, establishment of closer connections of training with practical activity, and thus promotes the formation of comprehensively developed personality and foreign language communicative competence of the future professionals of non-linguistic specialties. The integrative links between the study of special disciplines and a foreign language are aimed at improving the students' professional knowledge and the development of foreign language communicative competence.

The process of teaching foreign discourse in the system of higher education makes it possible to trace the dynamics of changes in goals and objectives, in accordance with the requirements of the time, social demand, modern labor market. There can be traced the transformations of forming the practical purpose of teaching foreign languages from the past to the present: teaching a foreign language - foreign speech teaching - teaching foreign speech activity - teaching foreign communication [10]. During practical language teaching the main goal is to integrate the ability to think and operate the language: read, write in a foreign language, listen, communicate in accordance with the communicativeneedsand situations. Communication is not defined as a simple process of information exchange, but the active interaction of the participants. In this case, the language acts as a means of such interaction [10]. The specialists, regardless of the field they work in, at the present stage must have a significant amount of professional and general information in a foreign language, special skills and abilities that are developed throughout the training period, and above all, the specialists should possess the necessary foreign language vocabulary.

Different types of knowledge and skills and the corresponding types of educational activities are integrated into a unified, multifaceted, versatile, scientifically substantiated learning process [11].
Given that the range of students' interests resides in scope of professional communication, teaching a foreign language based on professional activity significantly increases the language learning interest. Applying the integrative process in the training of a highly qualified specialist is impossible without the use of various methods of educational activities, since they depend on the efficiency of the educational process.

The main methodological principles providing the integration of language tasks are as follows: constant connection of theoretical information (knowledge) with its application; language knowledge in the system of language acquisition is not a result in itself, but an important means of forming, expressing and improving the thought; intense nature of learning: mastering the language should become an active process that will provide an organic combination of the four types of speech activity - reading and writing, auding and speaking; communication knowledge, speech skills and abilities should be considered as a condition and component of developmental learning (E. Dorofeeva, 2008).

Notable is that the integrative approach allows to apply a variety of types of_work in the classroom, while maintaining the principles of communication, situationality, originality, novelty and individuality. The classes are conducted continually, without pauses, with a variety of tasks. Their use requires exercises to develop all the language skills and abilities. Training involves the following stages: warming-up, presentation of material, practice, gradual transition from training exercises or tasks to fluent speech [14, p. 19]. This approach does not violate the logic of each subject and at the same time provides potential interaction between them.

In the process of learning a foreign language in order to achieve the communicative goals, students naturally integrate language skills. The similarity of learning professional and foreign language activities is manifested in the integrity of the following:

- objectives (mastering of each part of professional material and consequent mastering of the corresponding foreign language speech material);

- elements (separation of such elements of professional information, which would be consistent in its meaning with the elements of foreign language);

- components (acquisition of knowledge and skills of activity on specialty by acquiring knowledge and skills of foreign language and speech activities);

- methods (use of subject activity teaching methods adequate to methods of teaching foreign language activities); 
- control and learning outcome (provides for the determination of the advancement of knowledge and practical skills from each of the studied parts of professional and foreign language materials) [13].

In the context of the future specialists' foreign language training, the following features of integration of knowledge and skills are determined: taking into account the special role and place of a foreign language in the future specialists' professional training; constant integration of knowledge and skills, which contributes to the updating of professional training content; determination and maintaining of levels of foreign language competence for the specialists of different specializations; supporting the targeting of primary and secondary languages taking into account the specific needs and purpose of the specialist's professional activity; integration of knowledge and skills in the process of learning foreign languages for optimizing theoretical and practical components of professional training; ensuring the specialists' readiness for translation activity, taking into account the professional specifics [16].

The principles of integrative technologies of foreign language teaching are: the social nature of the knowledge structure, the authenticity of language and speech, the focus on the student's individuality, purposefulness and meaningfulness of the lesson [10]. The content of integrative technologies allows to consider the language as a whole, because learning of all the types of speech activities is performed simultaneously.

During learning activities under terms of applying the technologies mentioned, language is studied not in specific manifestations, i.e. in phonemes, morphemes, sentences, but in its entirety, by discussing the problem situations of real life, exchanging ideas, holding discussions, writing essays, etc. [10].
Pedagogical conditions for implementing the abovementioned technologies are identified by the researchers and the teachers in the following: integration of all the types of speech activity; correspondence of educational material to the age, level of language proficiency and students' professional orientation; integrity of educational works (articles, interviews, stories, etc.); debatability and openness for the views exchange that make up the nature of the lesson; application of the tasks for text processing, which have real opportunities for communication, expression of students' opinions and interests [1].

Thus, combining foreign language knowledge with the content of professional disciplines not only improves the future professionals' foreign language possession level, but also implements the speech functions in the subject content. On the other hand, integration involves the transformation of both substantive and procedural components of speech activity, which allows to improve the process of its comprehension and mastering.

Conclusions and perspectives for futher research. The analysis of theoretical bases of the concepts «integration», «integration in education» does not cover all the aspects of the given problem. The analysis of the obtained results testifies to the need for further developing of foreign language communicative competence, in particular applying the integrative approach in teaching a foreign language of professional orientation. That is why we see the prospect for further scientific research in the substantiation of applying the principles, methods, technologies and means of teaching a foreign language for professional purposes on the basis of an integrative approach.

\section{REFERENCES:}

1. Винокурцева И.Г. Приемы организации интерактивного чтения в философии Whole Language («Язык как целое»). Иностранные языки в школе. 2005. № 2. С. 69-74.

2. Гончаренко С., Кміт Я. Загальнотеоретичні аспекти інтеграції природного-наукових і методичних знань учнів. Шляхи освіти. 1997. № 1. С. 18.

3. Гончаренко С.У. Український педагогічний енциклопедичний словник ; вид. 2-е, доп. і випр. Рівне : Волинські обереги, 2011. 519 с.

4. Данилюк А.Я. Теория интеграции образования. Ростов-на-Дону : Рост. пед. ун-т, 2000. 440 с.

5. Дичківська І.М. Інноваційні педагогічні технології : навчальний посібник. Київ : Академвидав, 2004. 352 с.

6. Заскалета С. Застосування принципів міждисциплінарних зв'язків у процесі вивчення іноземної мови на факультеті іноземної фрілології. Наукові записки Вінницького державного педагогічного університету імені Михайла Коцюбинського. Серія «Філологія». 2018. Вип. 27. С. 134-140.

7. Іванчук М.Г. Інтегроване навчання: сутність та виховний потенціал (Виховання особистості молодшого школяра в умовах інтегрованого підходу до навчання). Чернівці : Рута, 2004. 99 с.

8. Козловська І.М. Теоретичні та методичні основи інтеграції знань учнів професійно-технічної школи : автореф. дис. ... докт. пед. наук : 13.00.04. Київ, 2004. 21 с.

9. Козловський Ю.М. Інтеграційні процеси в профресійній освіті: методологія, теорія, методики : монографія. Львів : Львівська політехніка, 2018. 420 с. 
10. Лавриш Ю.Е., Леонова О.М. Інтегративні технології при викладанні іноземної мови у вищому навчальному закладі. Теоретичні питання культури, освіти та виховання. 2015. № 51. С. 55-60.

11. Мартынова Р.Ю. Дидактическая сущность интегрированного процесса обучения. Наука і освіта. 2009. № 10. C. 197-202.

12. Мартинова Р.Ю. Сутність і структура процесуальної інтеграції професійної та іншомовної мовленнєвої діяльності. Науковий вісник Міжнародного гуманітарного університету. Серія «Філологія». 2012. Вип. 4. С. 63-69.

13. Мартинова Р.Ю. Цілісна загальнодидактична модель змісту навчання іноземних мов : монографрія. Київ : Вища шк., 2004. 454 с.

14. Морська Н.О. Інтегрований підхід до викладання іноземної мови. Вісник Національного університету «Львівська політехніка». Проблеми лінгвістики науково-технічного і художнього тексту та питання лінгвометодики. 2001. № 419. С. 18-20.

15. Проблеми інтеграції у сучасній професійній освіті: методологія, теорія, практика / за ред. І. Козловської та Я. Кміта. Львів : Сполом, 2004. 244 с.

16. Мукан Н.В., Пастирська І.Я., Кравець С.Ф. Можливості використання інтегративного підходу у профресійній іншомовній підготовці фахівців. Педагогіка формування творчої особистості у вищій і загальноосвітній школах. 2020. Вип. 69. С. 27-32.

17. Семеног О.М. Система професійної підготовки майбутніх учителів української мови і літератури (в умовах педагогічного університету) : дис. ... доктора пед. наук : 13.00.04. Київ, 2005. 476 с.

18. Шевчук К. Інтегрований підхід до навчання: ретроспективний аналіз. Наукові записки Вінницького державного педагогічного університету імені Михайла Коцюбинського. Серія «Педагогіка і психологія». 2007. № 20. C. 50-55. 